NOTE

\title{
Return movement of a humpback whale between the Antarctic Peninsula and American Samoa: a seasonal migration record
}

\author{
Jooke Robbins ${ }^{1, *}$, Luciano Dalla Rosa ${ }^{2,3,4}$, Judith M. Allen ${ }^{5}$, David K. Mattila ${ }^{6}$, \\ Eduardo R. Secchi ${ }^{2,4}$, Ari S. Friedlaender ${ }^{7}$, Peter T. Stevick ${ }^{5}$, Douglas P. Nowacek ${ }^{7,8}$, \\ Debbie Steel ${ }^{9}$
}

\author{
${ }^{1}$ Provincetown Center for Coastal Studies, 5 Holway Avenue, Provincetown, Massachusetts 02657, USA \\ ${ }^{2}$ Projeto Baleias/Brazilian Antarctic Program, Museu Oceanográfico ‘Prof. Eliézer C. Rios', FURG, Rio Grande, RS 96200-970, Brazil \\ ${ }^{3}$ Department of Zoology and Marine Mammal Research Unit, University of British Columbia, Room 247, AERL, \\ 2202 Main Mall, Vancouver, British Columbia V6T 1Z4, Canada \\ ${ }^{4}$ Laboratório de Tartarugas e Mamíferos Marinhos/Instituto de Oceanografia, Universidade Federal do Rio Grande-FURG, \\ Cx.P. 474, Rio Grande, RS 96201-900, Brazil \\ ${ }^{5}$ Antarctic Humpback Whale Catalog, Allied Whale, College of the Atlantic, Bar Harbor, Maine 04609, USA \\ ${ }^{6}$ Hawaiian Islands Humpback Whale National Marine Sanctuary, 726 S. Kihei Road, Kihei, Hawaii 96753, USA \\ ${ }^{7}$ Nicholas School of the Environment, and ${ }^{8}$ Pratt School of Engineering, Duke University Marine Laboratory, \\ 135 Duke Marine Lab Rd., Beaufort, North Carolina 28516, USA \\ ${ }^{9}$ Marine Mammal Institute, Oregon State University, 2030 SE Marine Science Drive, Newport, Oregon 97366, USA
}

\begin{abstract}
Humpback whales Megaptera novaeangliae are seasonal migrants that mate and calve at low latitudes and feed at mid- to high latitudes. Connections between most Southern Hemisphere breeding and feeding areas are not well understood, but are critical for assessing stock structure and human impacts. Photo-identification was performed to identify the feeding grounds of an Endangered sub-population that breeds in the central South Pacific Ocean (CSP). Identification photographs were obtained from 159 ind. at American Samoa and compared to 3508 Southern Hemisphere humpback whales in the Antarctic Humpback Whale Catalogue (AHWC), including 1352 from Antarctic feeding grounds. Two individuals from American Samoa were seen on 3 occasions at the Antarctic Peninsula. This is the first known feeding site for American Samoa and one of few reliably identified for the CSP. AHWC \#2950 was confirmed to have undertaken a round-trip movement of no less than $18840 \mathrm{~km}$, spanning 108 longitudinal degrees. This represents the largest mammalian migration known to date and a departure from historical assumptions about CSP migratory patterns. The frequency, causes, and fitness implications of such movements have yet to be determined. However, distance is the only known extrinsic barrier to humpback whale movement within oceans, and so maximum individual range is 1 factor potentially affecting population exchange and colonization of new habitats. The movement documented here may place this Endangered sub-population at risk if conservation efforts are relaxed in unidentified parts of its range. Yet, the ability of humpback whales to undertake such extensive movements may have also contributed to the apparent recovery of some populations versus other historically exploited whale species.
\end{abstract}

KEY WORDS: Migration $\cdot$ Humpback whale $\cdot$ Photo-ID $\cdot$ Spatial distribution $\cdot$ Conservation

\section{INTRODUCTION}

Humpback whales Megaptera novaeangliae are seasonal migrants that divide the year between low lati- tude breeding grounds and mid- to high-latitude feeding grounds. In the South Pacific, humpback whales mate and calve in tropical waters ranging from the east coast of Australia to South America. The International 
Whaling Commission (IWC) recognizes 3 distinct South Pacific breeding stocks and sub-stocks with limited longitudinal exchange (IWC 1998, Olavarría et al. 2007). Historically, individuals within a breeding stock were assumed to migrate more or less directly south to a corresponding Antarctic management area. However, the only 2 Discovery Tags (uniquely marked steel cylinders fired into live whales and recovered from carcasses in order to study whale movement during the whaling era) reliably linking central South Pacific Ocean (CSP) breeding areas to Antarctic feeding areas involved horizontal displacements of $10^{\circ}$ and $90^{\circ}$ (Table 1). More recent studies have detected considerable horizontal movement within the CSP (Garrigue et al. in press) as well as on Antarctic feeding grounds (Dalla Rosa et al. 2008). However, new data on seasonal migrations from the CSP have been limited (Hauser et al. 2010, D. Steel et al. unpubl. [Paper SC/60/SH 13 presented to the International Whaling Commission, IWC, Scientific Committee, May 2008. Available from the IWC.]).

Southern Hemisphere humpback whales were heavily depleted by commercial whaling in the 19th and 20th centuries (Chapman 1974, Clapham \& Baker 2002). Although the International Union for the Conservation of Nature (IUCN) no longer considers this species to be at risk of global extinction (Reilly et al. 2008), CSP populations have recently been elevated to an Endangered status (Childerhouse et al. 2008). Consequently, their range, migratory connections and critical habitats are of particular concern.

Here, we report the first known feeding site for humpback whales from American Samoa, one breeding area in the CSP. This finding involves the largest seasonal migration on record for a mammal, both in terms of its distance and horizontal displacement. It has potential implications for both the management of this endangered population and the resilience of this species.

\section{MATERIALS AND METHODS}

Humpback whale surveys were conducted annually in the near-shore waters of Tutuila, the main island of American Samoa, between 2003 and 2008. In total, 159 individual humpback whales were identified from the ventral pigmentation and shape of the flukes using established techniques (Katona \& Whitehead 1981). Fluke images and associated data were shared with several institutions, including the Antarctic Humpback Whale Catalogue (AHWC). They were visually compared to

Table 1. Megaptera novaeangliae. Published humpback whale movements between central South Pacific (CSP) breeding grounds and International Whaling Commission Antarctic management areas. The 2 'Movement' columns give the respective areas, with geographical coordinates (where reported), and dates for the start and end of the recorded movements. Two additional Discovery Tags indicated migration between the CSP and Antarctic Areas IV or I, but the former was listed as a fin whale when tagged (Mikhalev \& Tormosov 1997) and the latter could not be linked to a specific catch location (IWC 1998). AHWC: Antarctic Humpback Whale Catalogue

\begin{tabular}{|c|c|c|c|c|c|c|}
\hline \multirow[t]{2}{*}{ ID } & \multicolumn{2}{|c|}{ Movement } & \multicolumn{2}{|c|}{ —Distance — } & \multirow{2}{*}{$\begin{array}{l}\text { Time elapsed } \\
\text { (yr) }\end{array}$} & \multirow[t]{2}{*}{ Source } \\
\hline & Start & End & $\mathrm{km} \mathrm{l}$ & longitude $\left({ }^{\circ}\right)$ & & \\
\hline $\begin{array}{l}\text { Discovery Tag } \\
11201\end{array}$ & $\begin{array}{c}\text { Tonga } \\
21^{\circ} 02^{\prime} \mathrm{S}, 175^{\circ} 08^{\prime} \mathrm{W} \\
17 \text { Oct } 1952\end{array}$ & $\begin{array}{c}\text { Area I } \\
68^{\circ} 01^{\prime} \mathrm{S}, 95^{\circ} 45^{\prime} \mathrm{W} \\
3 \mathrm{Feb} 1957\end{array}$ & 7413 & 90 & 4.3 & Brown (1957) \\
\hline $\begin{array}{l}\text { Discovery Tags } \\
19946-7\end{array}$ & $\begin{array}{c}\text { Area V } \\
66^{\circ} 37^{\prime} \mathrm{S}, 174^{\circ} 48^{\prime} \mathrm{E} \\
28 \mathrm{Dec}^{\prime} 1957\end{array}$ & $\begin{array}{c}\text { Tonga } \\
21^{\circ} 02^{\prime} \mathrm{S}, 175^{\circ} 08^{\prime} \mathrm{W} \\
6 \mathrm{Aug} 1958\end{array}$ & 5116 & 10 & 0.6 & Dawbin (1959) \\
\hline $\begin{array}{l}\text { Satellite tag } \\
22854\end{array}$ & $\begin{array}{l}\text { Cook Islands } \\
\text { Not reported } \\
10 \text { Sep } 2006\end{array}$ & $\begin{array}{c}\text { Area VI }{ }^{\mathrm{a}} \\
65^{\circ} 06^{\prime} \mathrm{S}, 126^{\circ} 57.1^{\prime} \mathrm{W} \\
23 \mathrm{Jan} 2007\end{array}$ & $\sim 5400^{\mathrm{a}}$ & $\sim 33^{\mathrm{a}}$ & $0.4^{\mathrm{a}}$ & $\begin{array}{l}\text { Hauser et al. } \\
(2010)\end{array}$ \\
\hline AHWC\# 3234 & $\begin{array}{c}\text { American Samoa } \\
14^{\circ} 22.83^{\prime} \mathrm{S}, 170^{\circ} 45.81^{\prime} \mathrm{W} \\
3 \text { Oct } 2006\end{array}$ & $\begin{array}{c}\text { Area I } \\
64^{\circ} 39.91^{\prime} \mathrm{S}, 62^{\circ} 39.22^{\prime} \mathrm{W} \\
6 \text { May } 2009\end{array}$ & 9406 & 108 & 2.6 & Present study \\
\hline AHWC\# 2950 & $\begin{array}{c}\text { Area I } \\
64^{\circ} 35.13^{\prime} \mathrm{S}, 62^{\circ} 29.35^{\prime} \mathrm{W} \\
28 \mathrm{Jan}^{2} 2002\end{array}$ & $\begin{array}{c}\text { American Samoa } \\
14^{\circ} 12.30^{\prime} \mathrm{S}, 170^{\circ} 33.85^{\prime} \mathrm{W} \\
2 \text { Oct } 2005\end{array}$ & 9426 & 108 & 3.7 & Present study \\
\hline AHWC\# 2950 & $\begin{array}{c}\text { American Samoa } \\
14^{\circ} 12.30^{\prime} \mathrm{S}, 170^{\circ} 33.85^{\prime} \mathrm{W} \\
2 \text { Oct } 2005\end{array}$ & $\begin{array}{c}\text { Area I } \\
64^{\circ} 51.89^{\prime} \mathrm{S}, 62^{\circ} 29.12^{\prime} \mathrm{W} \\
16 \text { May } 2009\end{array}$ & 9414 & 108 & 3.6 & Present study \\
\hline
\end{tabular}




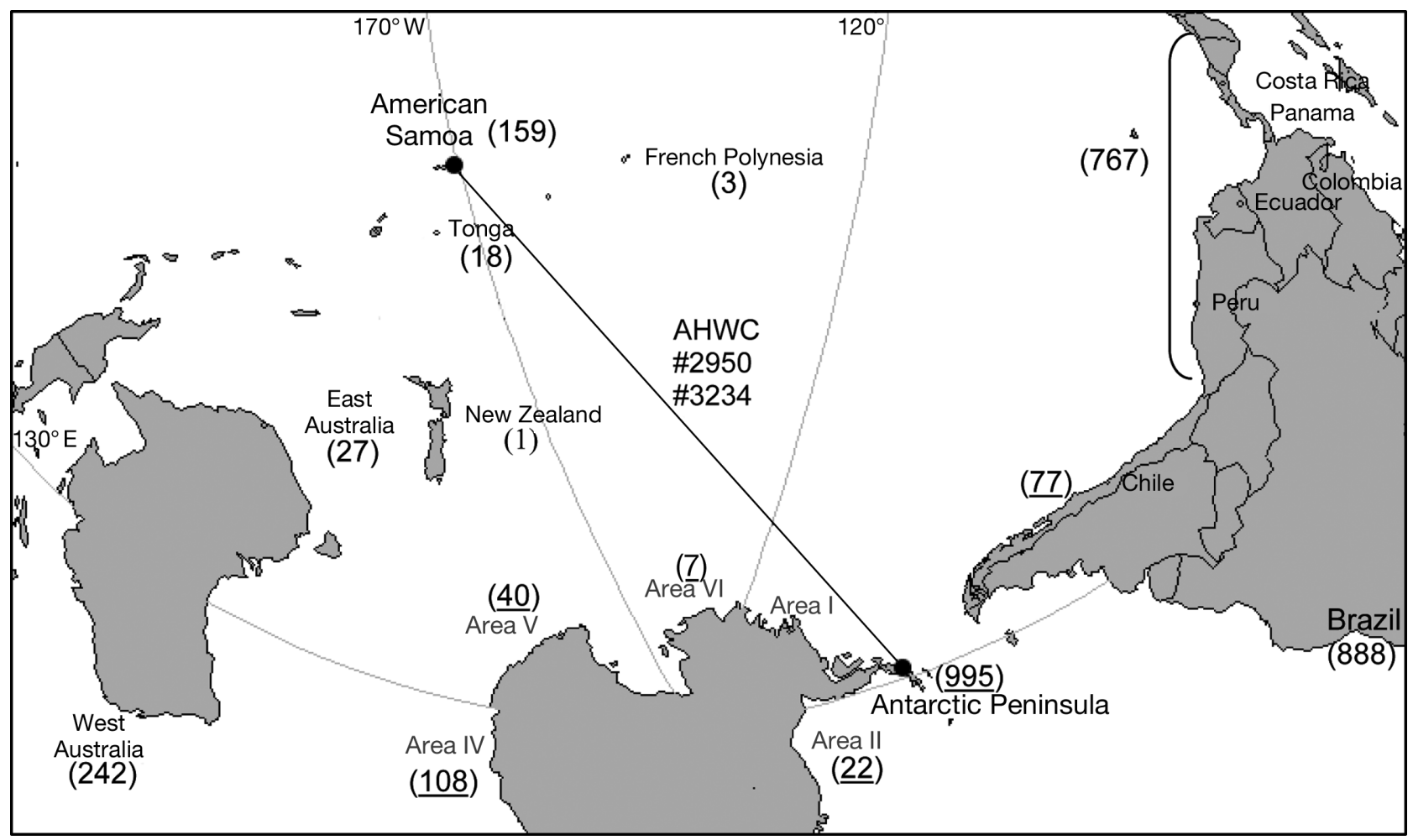

Fig. 1. Megaptera novaeangliae. Results of photographic matching between American Samoa and other Southern Hemisphere areas in the Antarctic Humpback Whale Catalogue (AHWC). The numbers of unique individuals are shown in parentheses by area, and feeding area samples are underlined. Antarctic Area III (117), St. Helena (2), Ghana (1), Gabon (78), South Africa (7), and Madagascar (226) are not shown. Regional sample sizes are not cumulative due to re-sightings of individuals between areas. The line between Costa Rica and Peru pools these areas to a total of 767 whales. The straight line indicates successful matches of 2 individuals (AHWC \#2950 and \#3234) between American Samoa and the Antarctic Peninsula. The largest 1-way distance between area sightings was $9426 \mathrm{~km}$ (108 longitudinal degrees). One individual undertook a round-trip movement from the Antarctic Peninsula with a minimum total distance of $18840 \mathrm{~km}$

3508 Southern Hemisphere humpback whales in the AHWC, including 1352 individuals photographed on Antarctic feeding grounds since 1981 (Fig. 1). Distances between matching sightings were calculated along a great circle route (Vincenty 1975, see www. movable-type.co.uk/scripts/latlong-vincenty.html). Sexes of matched individuals were determined by molecular genetics, as described in Olavarría et al. (2007)

\section{RESULTS AND DISCUSSION}

Photographic comparisons yielded 3 matches of 2 individuals (AHWC \#2950, male, and \#3234, female) between American Samoa and other Southern Hemisphere areas (Table 1). All matching photographs were from the Antarctic Peninsula in eastern Area I, 1 of 6 Antarctic management areas of the IWC. The minimum 1-way distance between area sightings ranged from 9406 to $9426 \mathrm{~km}$ and spanned 108 longitudinal degrees. AHWC\#2950 was photographed at the
Antarctic Peninsula both before and after its sighting at American Samoa, constituting a minimum roundtrip distance of $18840 \mathrm{~km}$. Sightings of this individual at the Antarctic Peninsula were $7.3 \mathrm{yr}$ and $31 \mathrm{~km}$ apart.

The Antarctic Peninsula is the first identified feeding ground for whales seen at American Samoa and one of very few confirmed for the CSP. Our results support historical evidence of CSP exchange with Antarctic Area I, which was once considered anomalous (Brown 1957). They also provide evidence of return movement to the Antarctic Peninsula from American Samoa. The Antarctic Peninsula is a well-established feeding ground for humpback whales that breed along the coast of western Central and South America (Stevick et al. 2004, Acevedo et al. 2007, Rasmussen et al. 2007). Our study yielded no direct matches between American Samoa and these other breeding areas (Fig. 1), and genetic analysis suggests little exchange between the CSP and South America (Olavarría et al. 2007). Given that the vast majority of the AHWC holdings from feeding grounds came from the Antarctic Peninsula, 
we cannot exclude the possibility that less well-studied Antarctic areas are equally or more important to this population. However, our results confirm that this endangered population exhibits some degree of mixing with adjacent, non-endangered populations. Additional research is recommended to clarify CSP migratory destinations in order to accurately model population recovery and to provide adequate protection against modern impacts.

Our documented return trip of no less than $18840 \mathrm{~km}$ is currently the longest movement on record for an individual mammal. One-way migration distances reported here exceed the previous mammalian migration record (also held by humpback whales; Rasmussen et al. 2007) by approximately $1000 \mathrm{~km}$. One case of inter-ocean exchange between breeding grounds involved a greater absolute distance between sightings (Stevick et al. 2010), but did not necessarily involve a longer seasonal migration. Our results indicate that both sexes can undertake extensive movements. It remains to be seen how frequent these movements are, and how movements within seasonal habitats may have contributed to the migration distance documented here.

Population persistence and recovery depends, in part, on the flexibility of individuals to seek out resources on the necessary scale (Dolman \& Sutherland 1995, Pichegru et al. 2010). Whereas some of the humpback whale breeding sites that were targeted by 19th century whaling remain at low density today, several major current breeding areas appear to have emerged more recently (Herman 1979, Reeves et al. 2001, Olavarría et al. 2007). It is conceivable that movements on the scale reported here, combined with a flexibility to colonize new habitats, may have played a role in the apparent recovery of humpback whales relative to other large whale species. These behaviors may also facilitate the response of this seasonal migrant to climate-related changes in the distribution of suitable habitats (e.g. Robinson et al. 2009). We cannot evaluate these hypotheses with available data, but recommend further study of the frequency, causes, and fitness implications of extreme movements in this species.

Acknowledgements. We thank the following individuals for their assistance: M. Bassoi, M.C. de O. Santos, D. Danilewicz, S. Fa'aumu, P. Flores, K. Jones, A. Kennedy, E. Lyman, I. Moreno, A. Tagarino, R. Tyson, V. Vaivai, J. Viechnicki, and J. Ward. We also thank the following institutions: American Samoa Department of Marine and Wildlife Resources, Brazilian Council for Scientific and Technological Development (CNPq), Brazilian Ministry of the Environment, Brazilian Navy, Fagatele Bay National Marine Sanctuary, Inter-ministerial Commission for the Resources of the Sea (CIRM-Brazil), International Fund for Animal Welfare (support for the South
Pacific Whale Research Consortium), National Science Foundation's Office of Polar Programs (grant number ANT-0739483), and US National Park Service. Research was conducted under NOAA/NMFS permits 774-1714 and 808-1735, Antarctic Conservation Act permit 2009-014, and the permission of the Government of American Samoa. S. Childerhouse and 1 anonymous reviewer provided helpful comments on the manuscript.

\section{LITERATURE CITED}

Acevedo J, Rasmussen K, Felix F, Castro C and others (2007) Migratory destinations of humpback whales from the Magellan Strait feeding ground, Southeast Pacific. Mar Mamm Sci 23:453-463

Brown SG (1957) Whale marks recovered during the Antarctic whaling season 1956/57. Norsk Hvalfangst-Tidende 10: 555-559

Chapman DG (1974) Estimation of population parameters of Antarctic baleen whales. In: Schevill WE (ed) The whale problem: a status report. Harvard University Press, Cambridge, MA, p 336-351

Childerhouse S, Jackson J, Baker CS, Gales N, Clapham PJ, Brownell RL Jr (2008) Megaptera novaeangliae (Oceania subpopulation). In: IUCN (ed) IUCN Red List of Threatened Species. Version 2009.2. Available at www.iucnredlist.org

Clapham PJ, Baker CS (2002) Whaling, modern. In: Perrin WF, Wursig B, Thewissen JGM (eds) Encyclopedia of marine mammals. Academic Press, San Diego, CA, p 1328-1332

> Dalla Rosa L, Secchi ER, Maia YG, Zerbini AN, Heide-Jørgensen MP (2008) Movements of satellite-monitored humpback whales on their feeding ground along the Antarctic Peninsula. Polar Biol 31:771-781

Dawbin WH (1959) New Zealand and South Pacific whale marking and recoveries to the end of 1958. Norsk Hvalfangst-Tidende 5:213-238

> Dolman PM, Sutherland WJ (1995) The response of bird populations to habitat loss. Ibis 137:S38-S46

Garrigue C, Constantine R, Poole M, Hauser N and others (in press) Movement of individual humpback whales between wintering grounds of Oceania (South Pacific), 1999 to 2004. J Cetacean Res Manag (Spec Issue)

Hauser N, Zerbini AN, Geyer Y, Heide-Jørgensen MP, Clapham P (2010) Movements of satellite-monitored humpback whales, Megaptera novaeangliae, from the Cook Islands. Mar Mamm Sci 26:679-685

Herman LM (1979) Humpback whales in Hawaiian waters: a study in historical ecology. Pac Sci 33:1-15

IWC (International Whaling Commission) (1998) Report of the Scientific Committee. Annex G. Report of the Sub-Committee on Comprehensive Assessment of Southern Hemisphere Humpback Whales. Rep Int Whal Comm 48: $170-182$

> Katona SK, Whitehead HP (1981) Identifying humpback whales using their natural markings. Polar Rec 20: 439-444

Mikhalev YA, Tormosov DD (1997) Corrected data about nonSoviet whale marks recovered by Soviet whaling fleets. Rep Int Whal Comm 47:1019-1027

> Olavarría C, Baker CS, Garrigue C, Poole M and others (2007) Population structure of South Pacific humpback whales and the origin of the eastern Polynesian breeding grounds. Mar Ecol Prog Ser 330:257-268

> Pichegru L, Ryan PG, Crawford RJM, van der Lingen CD, Grémillet D (2010) Behavioral inertia places a top marine 
predator at risk from environmental change in the Benguela upwelling system. Mar Biol 157:537-544

Rasmussen K, Palacios DM, Calambokidis J, Saborio MT and others (2007) Southern Hemisphere humpback whales wintering off Central America: insights from water temperature into the longest mammalian migration. Biol Lett 3:302-305

Reeves RR, Swartz SL, Wetmore SE, Clapham PJ (2001) Historical occurrence and distribution of humpback whales in the eastern and southern Caribbean Sea, based on data from American whaling logbooks. J Cetacean Res Manag 3:117-129

Reilly SB, Bannister JL, Best PB, Brown M and others (2008) Megaptera novaeangliae. In: IUCN (ed) IUCN Red List of Threatened Species. Version 2009.2. Available at www.iucnredlist.org

Editorial responsibility: Sascha Hooker,

St. Andrews, UK
Robinson RA, Crick HQP, Learmonth JA, Maclean IMD and others (2009) Travelling through a warming world: climate change and migratory species. Endang Species Res 7: $87-99$

Stevick PT, Aguayo A, Allen J, Avila IC and others (2004) Migrations of individually identified humpback whales between the Antarctic Peninsula and South America. J Cetacean Res Manag 6:109-113

Stevick PT, Neves MC, Johansen F, Engel MH, Allen J, Marcondes MCC, Carlson C (2010) A quarter of a world away: female humpback whale moves $10000 \mathrm{~km}$ between breeding areas. Biol Lett doi:10.1098/rsbl.2010. 0717

Vincenty T (1975) Direct and inverse solutions of geodesics on the ellipsoid with application of nested equations. Surv Rev 176:88-93

Submitted: July 14, 2010; Accepted: December 7, 2010 Proofs received from author(s): January 13, 2011 